\title{
Chemistry and analytical techniques for ent-kaurene-glycosides of Stevia rebaudiana Bertoni - A review
}

\author{
Neena Kumari ${ }^{*}$ and Suresh Kumar $^{2}$ \\ ${ }^{1}$ Department of Forest Products, Dr Y.S. Parmar University of Horticulture and Forestry, Nauni, Solan -173230 \\ (Himachal Pradesh), INDIA \\ ${ }^{2}$ Department of Forestry, Mizoram University, Aizawl-796004 (Mizoram), INDIA \\ *Corresponding author. E-mail: neenak.kashyap@gmail.com
}

Received: December 2, 2016; Revised received: April 28, 2017; Accepted: October 2, 2017

\begin{abstract}
The Stevia genus encompasses about 200 herbs and shrubs species. Stevia rebaudiana, one of the members has gained commercial importance as a natural low-calorie sweetener, due to the presence of high concentration of stevioside and rebaudioside - A ( $25 \%$ to $45 \%$ of stevioside content) in the leaves. The major processes involved in the production and quantification of steviol glycosides are extraction, purification and estimation. Various extraction methods have been used for extraction of steviol glycosides in the world. The extraction methods of steviol glycosides mostly differed at the stage of clarification of extracts. The present study is an attempt to summarize the scattered literature and reports on a single podium. Moreover, it also depicts upto date literature regarding numerous extraction, purification and quantitative estimation methods for steviol glycosides
\end{abstract}

Keywords: Extraction, Purification, Quantitative Analysis, Rebaudioside-A, Stevia, Stevioside

\section{INTRODUCTION}

Stevia rebaudiana is a perennial plant of tribe Eupatorieae and family Asteraceae. Stevia genus comprises of about 150-200 species of herbs and shrubs (Gentry, 1996) and native to Brazil and Paraguay regions of South America (Soejarto, 2002; Ramesh et al., 2006). $S$. rebaudiana is also known as sweet leaf, sweet herb, sweet weed and honey leaf (Carakostas et al., 2008; Inamake et al., 2010).In the native state it occurs on the edges of marshes or in grassland communities on soils with shallow water table (Shock,1982) with semi-humid subtropical climate, temperatures ranging from -6 to $43.8^{\circ} \mathrm{C}$, with an average of $23.8^{\circ} \mathrm{C}$ and rainfall ranging from 1500 to $1800 \mathrm{~mm}$ per annum (Yadav et al., 2011). S. rebaudiana is a short day plant that grows up to height of $1 \mathrm{~m}$ (Mishra et al., 2010). It has 2 to $3 \mathrm{~cm}$ long and elliptical leaves having alternate arrangement and bears a brittle stem and an extensive root system. Flowers are white in colour with a pale purple throat.They are small in size and arranged in the form of small corymbs (Madan et al., 2010; Yadav and Guleria 2012). The fruit is a five-ribbed spindle shaped achene (Katayama et al., 1976; Blumenthal, 1996).

The plant has gained commercial importance as a natural low calorie sweetener, due to the presence of high concentration of stevioside and rebaudioside-A in leaves (Kinghorn, 2002; Ramesh et al., 2006). Natural low caloric sweeteners not only create a calorie deficit but are also an appropriate tool against the health problems (Surana et al., 2006). Stevioside passes through the digestive processes without chemical break down, thus making stevia safe for the diabetic peoples (Yadav et al., 2011). Historically, plant has been used for various purposes throughout the world (Goyal et al., 2010). Leaves of $S$. rebaudiana has therapeutic properties like anticariogenic (Yabu et al.,1977; Gardana et al., 2010), antimicrobial (Satishkumar et al. 2008), antiviral (Kedik et al., 2009), antifungal (Silva et al., 2008), anti-hypertensive (Chan et al., 1998; Lee et al., 2001;Hsieh et al.,2003), anti-hyperglycaemic (Jeppesen et al., 2002; Benford et al., 2006), anti-tumour (Satishkumar et al., 2008; Kaushik et al., 2010), anti-inflammatory (Ghanta et al., 2007; Arya et al., 2012), hepatoprotective (Mohan and Robert, 2009), diuretic, anti-diarrhoeal, anti-human rotavirus activities (Das et al., 1992; Takahashi et al., 2001), anti-HIV (Takahashi et al., 1998) and immunomodulatory (Chatsudthipong and Muanprasat, 2009). In recent times, plant has gained significance in the pharmaceutical, food and cosmetic industries (Kienle, 2007; Hansen, 2010; Kienle, 2010; Kroyer, 2010; Herranz et al., 2010). Several studies have shown steviol glycosides as a substitute for sugar (Crammer and Ikan, 1986; Anton et al., 2010; Gasmalla et al., 2014).

There are numerous extraction, purification and estimation methods of steviol glycosides (Vanek et al., 2001; Choi et al., 2002; Yoda et al., 2003; Erkucuk et al., 2009) developed in the world. So in this regard, 
this paper is an attempt to summarize the scattered literature and reports on a single podium.

\section{CHEMICAL CONSTITUENTS}

Stevia rebaudiana is essentially well-known for a mixture of diterpenoid glycosides (steviol glycosides) in leaves, which are based on aglycone steviol (Prakash et al., 2008, Tavarini and Angelini, 2013). Goyal et al.(2010) reported eight sweet diterpenoid glycosides (steviol, stevioside, rebaudiosides (A, B, C, D), steviolbioside and dulcoside A) in leaves of the plant. However in the same year, Joint FAO/WHO Expert Committee on Food Additives (JECFA) listed nine different diterpenoid glycosides viz. Stevioside, rebaudioside-A, rebaudioside-B,rebaudioside-C, rebaudioside-D, rebaudioside-F, dulcoside-A, steviolbioside and rubusoside (JECFA, 2010). Out of various steviol glycosides reported to date, major glycosides are stevioside (6-10\%) and rebaudioside-A ( 2 to $4 \%$ ). While percentage of other minor glycosides in the leaves are 1-2 per cent only (Geuns, 2003). Some minor diterpene glycosides, differs in the substitution on $\mathrm{R}_{1}, \mathrm{R}_{2}$ and/or $\mathrm{R}_{3}$ of the ent -kaurene body (Table 1; Fig. 1).

Stevioside has chemical formula of a diterpene glycoside $\left(\mathrm{C}_{38} \mathrm{H}_{60} \mathrm{O}_{18}\right)$ and is accountable for the sweetening properties. It is about 300 times sweeter than sucrose (Debnath, 2008; Giuffre et al., 2013) (Table 2), but has an unpleasant bitter aftertaste (Schiffman et al., 2000; Abelyan et al., 2004; Mitchell, 2006; Carakostas et al., 2008). Rebaudioside-A, normally present in lower amount $(25 \%$ to $45 \%$ of stevioside) in leaves, possess no bitter aftertaste and has a sweetening power of 1.2 to 1.6 times higher than stevioside (Kinghorn and Soejarto, 1985). Reason behind the bitterness of the stevioside is the presence of essential oils, tannins and flavonoids (Phillips, 1987). Stevioside is stable at high temperature $\left(100^{\circ} \mathrm{C}\right)$ and over a range of $\mathrm{pH}$ values (3 to 9) (Chang and Cook, 1983; Kinghorn and Soejarto, 1985), nonfermentable and does not darken upon cooking (Kroyer, 2010; Abdullateef and Osman, 2012; Reshu et al., 2014). However, Serio (2010) reported the compound stability at $200^{\circ} \mathrm{C}$.

The minor diterpenoid glycosides are 30-80 times sweeter than sugar (Brandle, 1999; Oddone, 1999). Three new minor diterpenoid glycosides were isolated in addition to eight known steviol glycosides including stevioside, rebaudiosides $\mathrm{A}-\mathrm{F}$ and dulcoside $\mathrm{A}$. These compounds were 13-[(2-O $-\mathrm{b}-\mathrm{D}-$ glucopyranosyl - b - D - glucopyranosyl) oxy] 17hydroxy - kaur - 15 - en -18-oic acid b - D - glucopyranosyl ester, 13-[(2 O - b- D -glucopyranosyl -b- Dglucopyranosyl) oxy]kaur -16 - en -18 - oicacid - 6 - O - bxylopyranosyl b - D - glucopyranosyl ) ester and 13-[(2 - O - b - Dglucopyranosyl - b - D - glucopyranosyl)oxy] -17 oxo - kaur - 15 - en - 18 - oic acid b-D- glucopyranosyl ester (Chaturvedula et al., 2011). Chaturvedula et al. (2013a, b) isolated two new diterpenoid glycosides viz. rebaudioside-N and rebaudioside-O. Similarly, Rebaudioside-R and S have been isolated by Ibrahim et al. (2016). Chaturvedula (2014) recognised a minor penta $\beta$-D glucopyranosyl diterpene from $S$. rebaudiana leaves. Markovic et al. (2008) identified the compounds; nerol, safranal, aromadendrene, $\alpha$ - amorphene and T-muurolol and $\beta$ cyclocitral in leaves of $S$. rebaudiana. Prakash et al. (2012) reported three reduced derivatives of rebaudioside- B, C and D by using palladium hydroxide as catalyst. Prakash et al. (2011) evaluated steviol glycosides in mock beverage solutions by simulating formulations used in root beer soft drinks $(\mathrm{pH} 4.2)$, lemon-lime soft drinks ( $\mathrm{pH} 3.8$ ) and commercial cola soft drinks ( $\mathrm{pH} 2.8$ and $\mathrm{pH}$ 3.2) but lacking the flavour components. Results indicated that steviol glycoside yielded two minor compounds (13-[(2-O- $\beta-\mathrm{D}$ glucopyranosyl-3-O- $\beta$-D-gluopyranosyl- $\beta-D-$

glucopyranosyl)oxy] ent-kaur-15-en-19-oic acid $\beta$-Dglucopyranosyl ester and 13-[(2-O- $\beta$-Dglucopyranosyl-3-O- $\beta$-D-glucopyranosyl- $\beta$-Dglucopyranosyl)oxy]-16 $\beta$-hydroxy-ent-kauran-19-oic acid $\beta$-D-glucopyranosyl ester) on the basis of MS and hydrolysis studies.

Besides having sweet tasting diterpenoid glycosides and some minor glycosides, $S$. rebaudiana leaves accumulate several other important chemical constituents, such as flavonoids, alkaloids, hydroxycinnamic acid, vitamins, phytosterols, jhanol, austroinulin, 6-0-acetyl austroinulin, $\beta$-amyrin acetate and lupeol esters in leaves and flowers (Darise et al., 1983; Kinghorn and Soejarto, 1985). Labdane type diterpenoids, called sterbins, I-N, A---H and $\mathrm{Q}_{1}-\mathrm{Q}_{5}$ (Oshima et al,. 1986 and 1988; McGarvey et al., 2003; Kamauchi et al., 2015); bactericide agents (Koshiro, 1980) and gums as well as organic acids (Cheng and Chang, 1983) have also been reported in leaves.

Cioni et al., (2006) identified forty components like spathulenol (13.4-40.9\%), caryophyllene oxide (1.3$18.7 \%)$, beta-caryophyllene $(2.1-16.0 \%)$ and beta pinene $(5.5-21.5 \%)$ in the essential oil of the aerial parts of $S$. rebaudiana genotypes cultivated on the Tuscan coast (Italy) through using crystal chromatography and GC/MS (Gas Chromatography/ Mass Spectroscopy). However, some new essential oil compounds, such as ledene oxide-(II), beta-guaiene, geranyl vinyl ether, tricyclo (5.2.2.0 (1, 6) undecan-3-ol, indole, aristolene epoxide, 1, 2, 3, 5, 6, 7, 8, 8a-octahydro-1, 4 -dione and 2, 6, 6-trimethyl-2-cyclohexene-1, 4dionewere were identified for the first time by Hossain et al., (2010). Additionally, twenty four compounds were also identified viz. betulin, $\alpha$-amyrin, cyclopropyl ursane-type triterpene, 13, 27-cycloursan-3-ol and acetate $(3 \beta, 13 \beta, 14 \beta)$ etc. (Lasekan and Naidu, 2013). 
Table 1. Diterpenoid glycosides of $S$. rebaudiana.

\begin{tabular}{|c|c|c|c|}
\hline Name of compound & $\mathbf{R}_{\mathbf{1}}$ & $\mathbf{R}_{\mathbf{2}}$ & Reference(s) \\
\hline Steviol monoside & $\mathrm{H}$ & Glc $\beta 1-$ & Kaur et al., 2014 \\
\hline $\begin{array}{l}\text { Stevioside } \\
\text { Steviolbioside }\end{array}$ & $\begin{array}{l}\text { Glc } \beta 1- \\
\mathrm{H}\end{array}$ & $\begin{array}{l}\text { Glc } \beta 1-2 \mathrm{Glc} \beta 1- \\
\text { Glc } \beta 1-2 \mathrm{Glc} \beta 1-\end{array}$ & Kaur et al., 2014 \\
\hline Rebaudioside A & Glc $\beta 1-$ & Glc $\beta 1-2(\mathrm{Glc} \beta 1-3) \mathrm{Glc} \beta 1-$ & Carakostas et al., 2008 \\
\hline Rebaudioside B & $\mathrm{H}$ & Glc $\beta 1-2(\mathrm{Glc} \beta 1-3) \mathrm{Glc} \beta 1-$ & Kaur et al., 2014 \\
\hline Rebaudioside C & Glc $\beta 1-$ & Rha $\alpha 1-2($ Glc $\beta 1-3)$ Glc $\beta 1-$ & JECFA, 2010 \\
\hline Rebaudioside D & Glc $\beta 1-2$ Glc $\beta 1$ & Glc $\beta 1-2(\operatorname{Glc} \beta 1-3)$ Glc $\beta 1-$ & Prakash et al., 2014a \\
\hline Rebaudioside E & Glc $\beta 1-2$ Glc $\beta 1-$ & Glc $\beta 1-2$ Glc $\beta 1-$ & \\
\hline Rebaudioside F & Glc $\beta 1-$ & Xyl $\beta 1-2(\mathrm{Glc} \beta 1-3) \mathrm{Glc} \beta 1-$ & JECFA, 2010 \\
\hline Rebaudioside G & Glc $\beta 1-$ & Glc $\beta 1-3$ Glc $\beta 1--$ & Wolwer, 2012 \\
\hline Rebaudioside $\mathrm{H}$ & Glc $\beta 1-$ & $\begin{array}{l}\text { Glc } \beta 1-3 R h a \alpha 1-2(\text { Glc } \beta 1-3) \\
\text { Glc } \beta 1-\end{array}$ & Wolwer, 2012 \\
\hline Rebaudioside I & Glc $\beta 1-3 \mathrm{Glc} \beta 1-$ & Glc $\beta 1-2(\mathrm{Glc} \beta 1-3) \mathrm{Glc} \beta 1-$ & Wolwer, 2012 \\
\hline Rebaudioside $\mathrm{J}$ & Rha 1 1-2Glc $\beta 1-$ & Glc $\beta 1-2(\mathrm{Glc} \beta 1-3) \mathrm{Glc} \beta 1-$ & Wolwer, 2012 \\
\hline Rebaudioside K & Glc $\beta 1-2$ Glc $\beta 1-$ & Rha $\alpha 1-2(\mathrm{Glc} \beta 1-3) \mathrm{Glc} \beta 1-$ & Wolwer, 2012 \\
\hline Rebaudioside L & Glc $\beta 1-$ & $\begin{array}{l}\text { Glc } \beta 1-6 \mathrm{Glc} \beta 1-2(\mathrm{Glc} \beta 1-3) \\
\text { Glc } \beta 1-\end{array}$ & Wolwer, 2012 \\
\hline Rebaudioside M & Glc $\beta 1-2(\mathrm{Glc} \beta 1-3) \mathrm{Glc} \beta 1--$ & Glc $\beta 1-2(\operatorname{Glc} \beta 1-3)$ Glc $\beta 1-$ & Prakash et al., 2014b \\
\hline Rebaudioside N & Rha $\alpha 1-2(\mathrm{Glc} \beta 1-3) \mathrm{Glc} \beta 1-$ & Glc $\beta 1-2(\mathrm{Glc} \beta 1-3) \mathrm{Glc} \beta 1-$ & Chaturvedula et al., 2013b \\
\hline $\begin{array}{l}\text { Rebaudioside O } \\
\text { Rebaudioside R }\end{array}$ & $\begin{array}{l}\text { Glc } \beta 1-3 R h a \alpha 1-2(\operatorname{Glc} \beta 1-3) \text { Glc } \beta 1- \\
-\end{array}$ & $\begin{array}{l}\text { Glc } \beta 1-2(\mathrm{Glc} \beta 1-3) \mathrm{Glc} \beta 1- \\
-\end{array}$ & $\begin{array}{l}\text { Chaturvedula et al., 2013a } \\
\text { Ibrahim et al., } 2016\end{array}$ \\
\hline Rebaudioside S & - & - & Ibrahim et al., 2016 \\
\hline
\end{tabular}

Glc $=$ Glucose; Rha $=$ Rhamnose Xyl $=$ Xylose

Table 2. Relative sweetening power of diterpene glycosides of $S$. rebaudiana.

\begin{tabular}{lcccc}
\hline Diterpene glycoside & \multicolumn{4}{c}{ Relative sweetening power } \\
\cline { 2 - 5 } & Sharma et al., 2009 & Puri et al., 2011 & Carkostas et al., 2012 & Prakash et al., 2014 \\
\hline Stevioside & $100-270$ & $250-300$ & $150-250$ & 210 \\
Steviol & nd & $\mathrm{Nd}$ & $\mathrm{nd}$ & nd \\
Steviolbioside & $10-15$ & $\mathrm{Nd}$ & 90 & 90 \\
Rebaudioside-A & $150-320$ & $350-450$ & $200-300$ & 200 \\
Rebaudioside-B & $10-14$ & $300-350$ & 150 & 150 \\
Rebaudioside-C & $40-60$ & $50-120$ & 30 & 30 \\
Rebaudioside-D & $200-250$ & $200-300$ & 221 & 221 \\
Rebaudioside-E & $150-200$ & $250-300$ & $\mathrm{nd}$ & 174 \\
Rebaudioside-F & nd & $\mathrm{Nd}$ & $\mathrm{nd}$ & 200 \\
Rebaudioside-M & $\mathrm{nd}$ & $\mathrm{Nd}$ & $\mathrm{nd}$ & 250 \\
Rubusoside & $\mathrm{nd}$ & $\mathrm{Nd}$ & $\mathrm{nd}$ & 114 \\
Dulcoside-A & $40-60$ & $20-120$ & 30 & 30 \\
Dulcoside-B & $40-60$ & $\mathrm{Nd}$ & $\mathrm{nd}$ & $\mathrm{nd}$ \\
\hline
\end{tabular}

nd $=$ not determined

\section{EXTRACTION OF MAJOR SWEET COMPOUNDS}

Worldwide, there are many patents for steviol glycosides extraction (Giavanetto, 1990; Payzant et al., 1999; Jonnala et al. 2006). The main processing steps involved in the production of steviol glycosides comprise of extraction, pretreatment, separation and refining. Water is most popular solvent used for extraction; however, methanol/ethanol alone or in combination with water is also used for extracting the sweet diterpenoid glycosides. The extract obtained 
after solvent extraction contains dark brown colour and possess leaf pigments, soluble polysaccharides, proteins, pectins, flavonoids and other impurities. Less polar, other non-polar compounds and chlorophyll are removed with solvents such as chloroform/hexane (Masuyama 1980, Kinghorn et al., 1982).

Plentiful extraction methods have been used for extraction of sweet steviol glycosides (Table 3) but, conventional solvent extraction is the most commonly used method (Puri et al., 2012). Extraction of steviol glycosides from the leaves is often done by water (Inamake et al., 2010; Rao et al., 2012; Afandi et al., 2013). The crude extract so obtained, is dark brown, foul-smelling and bitter-tasting. Consequently, further purification is essential for preparation of quality products ( $\geq 90 \%$ purity). Hot water is used for extraction of the same, as rebaudioside- $\mathrm{A}$ is more soluble than stevioside in water (Mondaca et al., 2012). More solubility of rebaudioside-A in water than stevioside is preferably due to the presence of additional glucose unit in its molecule (Kohda et al., 1976). On the other hand, Abou et al. (2010) found that stevia sweeteners were highly soluble in methanol and less soluble in water. On this basis, Liu et al. (1997) extracted stevioside from $S$. rebaudiana leaves with hot methanol. Pol et al. (2007) used pressurized fluid extraction method for the extraction of stevioside from $S$. rebaudiana leaves using methanol and water. Conventional extraction methods have few demerits over the non-conventional extraction methods like their lower yields, lack of selectivity and use of large volume of organic solvents. Sorecently, modern extraction methods such as pressurized hot water extraction, microwave assisted extraction (MAE), ultrasound assisted extraction (UAE), enzyme assisted extraction, and supercritical fluid extraction have been developed (Puri et al., 2012; Khoddami et al., 2013; Piasecka et al., 2014; Tiwari et al., 2014). Conventional extraction processes are time consuming and involve use of large amounts of solvents. However, improved methods such as UAE and MAE techniques have some advantages over conventional extraction methods viz. reduction in extraction time, higher extract yield and less solvent consumption. MAE and UAE techniques are much easier and effective techniques as they produce extracts with similar qualitative characteristics, however with high quantitative differences (Khaled et al., 2015).MAE yielded maximum amount of stevioside $(0.7658 \mathrm{mg} / \mathrm{g}$ of dry leaf powder) with lesser extraction time (120 seconds) and a little solvent amount used $(10 \mathrm{ml} / \mathrm{g})$ as compared to conventional method (Javad et al., 2014). On the other hand, Zlabur et al. (2015) compared UAE with conventional solvent extraction and found maximum yield of steviol glycosides (stevioside: $96.48 \mathrm{mg} \mathrm{g}^{-1}$ extract; and rebaudioside-A content: $36.92 \mathrm{mg} \mathrm{g}^{-1}$ extract), total phenolic compounds and flavonoids with UAE. How- ever, on comparison with UAE, Jaitak et al. (2009) reported MAE method as a fast and capable extraction method for stevioside estimation. They suspended powdered leaf samples of $100 \mathrm{mg}$ in $10 \mathrm{ml}$ of different solvents (methanol, ethanol, water) and mixture of solvents (methanol: water: 80:20, ethanol: water: 80:20), filtered, concentrated and dried. Extraction was done at different power levels ranging from 20 to $160 \mathrm{~W}$ with extraction time ranging from 30 seconds to5 minutes and temperature from $10-90^{\circ}$ C. MAE yielded 8.64 and 2.34 percent of stevioside and rebaudioside-A, respectively, while UAE yielded 4.20 and 1.98 percent of stevioside and rebaudiosideA, respectively.

Other efficient methods of extracting steviol glycosides are PHWE (Pressurized Hot Water Extraction) and SCFE (Supercritical Fluid Extraction). Teo et al. (2009) reported higher extraction efficiency of PHWE and MAE as compared to heating under reflux. Extraction of $S$. rebaudiana plant samples were carried out with water at different extraction temperature for different periods. Maximum stevioside $(2137.8 \mathrm{mg} / 100 \mathrm{gm})$ and rebaudioside-A yield (2080.7 $\mathrm{mg} / 100 \mathrm{gm}$ ) was found with MAE for extraction period of 20 minutes. In SCFE method, glycosides from stevia leaves were obtained in two steps; extraction with $\mathrm{CO}_{2}$ at 200 bar pressure and $30^{\circ} \mathrm{C}$ temperature and extraction with $\mathrm{CO}_{2}$ and water (Pasquel et al., 2000; Choi et al., 2002; Yoda et al., 2003; Erkucuk et al., 2009). While, patent has claimed that $\mathrm{CO}_{2}$ could be used as a solvent and methanol, ethanol and acetone as a cosolvant for steviol glycosides extraction (Kienle, 1990).

Extractions of sweet glycosides using various enzymes have been also used successfully (Puri et al., 2012; Rao et al., 2015). Puri et al. (2012) revealed a novel enzyme-mediated extraction (EME) method for stevioside extraction from leaves of $S$. rebaudiana. The study investigated the effects of cellulase, hemicellulase and pectinase enzymes on stevioside yield. Hemicellulase gave the highest stevioside yield $(369.23 \pm 0.11 \mu \mathrm{g})$ in 1 hour with comparison to cellulase $(359 \pm 0.30 \mu \mathrm{g})$ and pectinases $(333 \pm 0.55$ $\mu \mathrm{g})$. Enzymes used for stevioside extraction in both studies were cellulase, hemicellulase and pectinase. Rao et al. (2015) extracted stevioside through treatment of dry leaves of stevia with the help of hydrolytic enzymes aided by transition metal salts $\left(\mathrm{FeCl}_{3}\right)$. The metal salt assisted enzyme extraction of stevioside resulted in increased stevioside yield to 72 per cent with 98 per cent purity.

\section{PURIFICATION OF MAJOR SWEET COM- POUNDS}

After extraction, extract purification is needed. Various methods for extraction of steviol glycosides mostly differ at the stage of clarification of extracts. Extract 
Table 3. Extraction methods for diterpene glycosides of $S$. rebaudiana.

\begin{tabular}{|c|c|c|c|}
\hline \multicolumn{2}{|l|}{ Extraction methods } & \multicolumn{2}{|c|}{ Reference(s) } \\
\hline \multicolumn{2}{|l|}{ Water extraction } & \multicolumn{2}{|c|}{$\begin{array}{l}\text { Abou et al., 2010; Inamake et al., 2010; Rao et al., 2012; Afandi et al., 2013; } \\
\text { Deshmukh and Kedari, 2014; Gonzalez et al., } 2014\end{array}$} \\
\hline \multicolumn{2}{|l|}{ Methanol extraction } & \multicolumn{2}{|c|}{ Liu et al., 1997; Pol et al., 2007; Deshmukh and Kedari, 2014} \\
\hline \multicolumn{2}{|l|}{ Ethanol extraction } & \multicolumn{2}{|c|}{ Erkucuk et al., 2009; Deshmukh and Kedari, 2014} \\
\hline \multicolumn{2}{|c|}{ Pressurized fluid extraction (PFE) } & \multicolumn{2}{|c|}{ Pol et al., 2007} \\
\hline \multicolumn{2}{|c|}{ Microwave-assisted extraction (MAE) } & \multicolumn{2}{|c|}{ Jataik et al., 2009; Teo et al., 2009; Javad et al., 2014} \\
\hline \multicolumn{2}{|c|}{ Ultrasonic-assisted Extraction (UAE) } & \multicolumn{2}{|c|}{ Zlabur et al., 2015} \\
\hline \multicolumn{2}{|c|}{ Pressurized hot water extraction(PHWE) } & \multicolumn{2}{|c|}{ Teo et al., 2009; Tiwari et al., 2014} \\
\hline \multicolumn{2}{|c|}{ Supercritical fluid extraction (SFE) } & \multirow{2}{*}{\multicolumn{2}{|c|}{$\begin{array}{l}\text { Pasquel et al., 2000; Choi et al., 2002; Yoda et al., 2003; Pol et al., 2007; } \\
\text { Erkucuk et al., 2009 } \\
\text { Puri et al. 2012; Rao et al. } 2015\end{array}$}} \\
\hline \multicolumn{2}{|l|}{ Enzymatic extraction } & & \\
\hline Analytical method & \multicolumn{2}{|l|}{ Columns } & References \\
\hline HPLC & \multicolumn{2}{|l|}{ Amino } & $\begin{array}{l}\text { Kolb et al., 2001; Woelwer et al., 2010; Hoekstra et al., 2009; } \\
\text { Kumari et al., 2016 }\end{array}$ \\
\hline HPLC & \multicolumn{2}{|l|}{$\mathrm{C} 18$} & $\begin{array}{l}\text { Vanek et al., 2001; Abou et al., 2010; Afandi et al., 2013; Gonza- } \\
\text { lez et al., 2015; Gonzalez et al., 2014; Kubica et al., 2015; Samah } \\
\text { et al., 2013; Javad et al., } 2014\end{array}$ \\
\hline HPLC & \multicolumn{2}{|l|}{ HILIC } & Wolwer et al., 2010; Zimmermann et al., 2011 \\
\hline HPLC & \multicolumn{2}{|c|}{ HILIC and Develosil ODS HG } & Lorenzo et al., 2014 \\
\hline RPLC & \multicolumn{2}{|c|}{$\mathrm{C} 18$ and amide } & Fu et al., 2012 \\
\hline RP-HPLC & \multicolumn{2}{|l|}{ Reverse phase $\mathrm{C} 18$} & Chaturvedula and Zamora, 2014; Rodenburg et al., 2016 \\
\hline
\end{tabular}

purification is an important step as it reduces the chances of occurrence of problems afterwards. On the other hand, purification processes have some demerits viz. organic solvents and metallic ions leave residue and thus harming human health whereas application of ultra filtration membranes and other advanced technologies increases final cost of the products.

Rebaudioside-A is commercially more desirable compound due to its more pleasant sweet taste than stevioside. Besides, separation of rebaudioside-A from other steviol glycosides is a tricky job, as all compounds are having almost similar chemical structures. Several patents have mentioned the purification of steviol glycosides (Abelyan et al., 2010; Magomet et al., 2011; Purkayastha et al., 2012). In these patents, leaves were dried and powdered, extracted with water followed by filtration and the filtrate so obtained was treated with calcium hydroxide and iron chloride. The filtrate was deionized using amberlite beds e.g., amberlite FPC23H, amberlite FPA51 and amberlite FPA98Cl. The filtrate was vacuum dried, concentrated and spray dried. The dried material was extracted with methanol at 20 to $25^{\circ} \mathrm{C}$ for 0.5 to 1.0 hour with agitation. Consequently, precipitation occurred and solution was filtered to obtain stevioside precipitate. The filtered precipitate was dried and analyzed to obtain about $90 \%$ stevioside. The remaining solution was evaporated to remove methanol and vacuum dried. Extract obtained is dissolved in ethanol and filtered to get $90 \%$ rebaudioside-A.
Membranes have been utilised to obtain each fractional component of a solution on the basis of molecular weight differences and have been applied to remove impurities from fermentation broth (Kuo and Chiang, 1987) and prefiltered fruit juices ( $\mathrm{Yu}$ and Chiang, 1986). Membrane processes have some advantages over other separation processes like occurrence at room temperature without phase change and with no heating or solvent involved. Fuh and Chiang (1990)

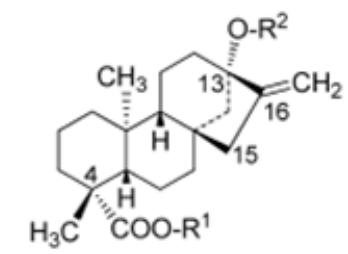

Structure 1

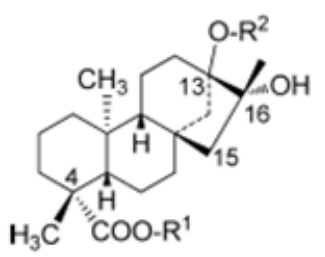

Structure 3

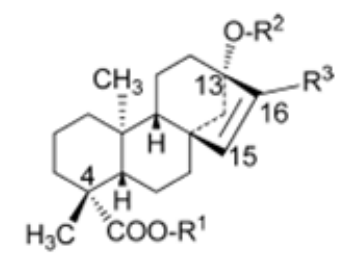

Structure 2

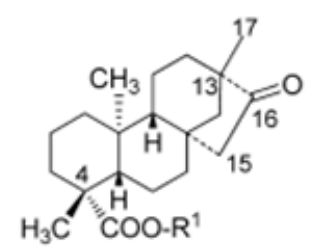

Structure 4
Fig. 1. Ent-kaurene body structures of steviol glycosides (Woelwer, 2012). 
applied membranes for carrying out ultrafiltration, diafiltration and reverse osmosis to remove majority of the pigments in $S$. rebaudiana leaf extract $(>90 \%)$. However, nano filtration practice has also been applied to purify the stevia extract (Zhang et al., 2000). Chaya et al. (2011) purified stevia extract through ultrafiltration membranes using four different ultrafiltration membranes of $5,10,30$ and $100 \mathrm{kDa}$ molecular weights. $30 \mathrm{kDa}$ membrane was found to be most appropriate.Vanneste et al. (2011) evaluated the performance of tailor-made polyethersulphone (PES) membranes for purification of steviol glycosides from $S$. rebaudiana. Similarly, Roy and De (2014) attempted to purify the steviol glycosides by using polymer blend of cellulose acetate phthalate (CAP) and polyacrylonitrile (PAN). Optimum flux, recovery and purity were $11 \mathrm{~L} / \mathrm{m}^{2} \mathrm{~h}, 68 \%$ and $34 \%$, respectively. Furthermore, inorganic salt treatment, ion exchange, adsorption column chromatography, adsorption by activated charcoal and use of macroporous resins have been widely used for clarification of stevia sweeteners (Akashi et al,. 1975; Okane and Kamata, 1977; Takamura et al., 1977; Ishizone, 1979; Kuroda and Kamiyama, 1979; Cheng et al., 1985; Fuh and Chiang, 1990; He et al., 1994; Rajab et al., 2009; Li et al., 2012; Deshmukhand Kedari, 2014; Kaur et al., 2014; Hubert et al., 2015; Anvari and Khayat, 2016). Selective adsorption using zeolites was also found suitable for stevia extract purification (Mantovaneli et al., 2004; Silva et al., 2007).

\section{QUANTITATIVE ESTIMATION OF STEVIOL GLYCOSIDES}

Various quantitative methods have been used to evaluate the distribution and per cent of sweetent-kaurene glycosides in $S$. rebaudiana. Thin layer chromatography (Nikolova et al., 1994),High Performance Liquid Chromatography (HPLC) (Kolb et al., 2001; Woelwer et al., 2010; Pieri et al., 2011; Samah et al., 2013; Lorenzo et al., 2014; Gonzalez et al., 2015; Kumari and Chandra, 2015; Kumari et al., 2016a), High Pressure Thin Layer Chromatography (HPTLC) (Chester et al., 2012, Saifi et al., 2014), Reverse Phase High Pressure Liquid Chromatography (RP-HPLC) (Jadhao et al., 2011, Chaturvedula and Zamora, 2014; Meneni and Chaturvedula, 2015), Ultra High Pressure Liquid Chromatography (UHPLC) (Gardana et al,. 2010; Cacciola et al., 2011), HPLCUV (Gonzalez et al., 2014), Liquid chromatography (LC), counter current chromatography (Huang et al., 2010; Englert et al., 2016), capillary zone electrophoresis, micellar kinetic capillary electrophoresis (Mauri et al., 1996; Dacome et al., 2005) and near infrared reflectance spectroscopy (Hearn and Subedi, 2009)have been used to quantify steviol glycosides from $S$. rebaudiana. However, HPLC is the most commonly used method (Table 4). Saifi et al. (2014) developed a validated HPTLC method for simultaneous identification and quantification of stevioside and rebaudioside-A from $S$. rebaudiana leaf extract. Stevioside and rebaudioside-A recovery was 98.97 and $97.68 \%$, respectively. Stevioside per cent ranged from 3.63 to $7.80 \%$ in $S$. rebaudiana leaves collected from Haryana and Kashmir, respectively. However, rebaudioside-A per cent varied from 1.74 to $4.40 \%$ in leaves collected from Haryana and Madhya Pradesh, respectively. Gonzalez et al. (2014) determined the per cent of dulcoside-A, steviolbioside, rebaudioside- $\mathrm{C}$ and rebaudioside-B in Morita II and Criolla varieties of $S$. rebaudiana through using isocratic HPLC-UV method. Average recovery varied between 92.29 to $104.49 \%$ for the minor glycosides (dulcoside A, steviolbioside, rebaudioside-C and rebaudioside-B). Dulcoside-Aand rebaudioside-C content $(\%)$ varied between $0.4-0.7$ and $1-2 \%$, respectively, in both varieties. Kumari et al. (2016) reported the effects of different growing conditions (open field and polyhouse) on stevioside and rebaudioside-A per centin $S$. rebaudiana leaves using HPLC method. Maximum stevioside $(9.19 \%)$ and rebaudioside-A content $(7.00 \%)$ was found in leaves under polyhouse and open field conditions, respectively. However, minimum stevioside and rebaudioside-A content $(<1.00 \%)$ was found in green and woody stems of the plants.

Steviol glycosides have been separated using various columns viz. hydroxyapatite (Kasai et al., 1987), silica gel (Nikolova et al., 1994), hydrophilic (Hashimoto et al., 1978) and size exclusion (Ahmed and Dobberstein, 1982) columns. Amino bonded columns have been commonly employed for the analysis of steviol glycosides (Kolb et al., 2001; Ahmed and Smith, 2002; Hoekstra et al., 2009; Musa et al., 2014). Amino columns have also been used to determine stevioside and related glycosides content in foods and beverages (Fujinuma et al., 1986; Kitada et al., 1989). Ahmed et al. (1980) used HPLC technique for determination of stevioside and rebaudioside- B per cent after conversion to p-promophenacyl esters. Application of amino columns for steviol glycosides analysis is burden some particularly for aglycone steviol, as steviol glycosides retains poorly on the column and decreases its efficiency. Therefore, RP-HPLC has been employed for the quantification of steviol glycosides (Minne et al., 2004; Martono et al., 2016). Two-dimensional reversed-phase liquid chromatography/hydrophilic interaction liquid chromatography (2D-RPLC/HILIC) have been used for characterization of diterpene glycosides from $S$. rebaudiana by using $\mathrm{C} 18$ and amide columns (Fu et al., 2012). As a result, the methods uccessfully purified the low-abundance compounds from natural products. Liquid Chromatography with Ultraviolet detection method was used for simultaneous analysis of steviol and other glycosides using a 
mixed mode reverse phase weak anion exchange chromatography column (Jaworska et al., 2012). Similarly, Ayyappa et al. (2015) developed electro kinetic chromatographic method for the simultaneous separation and determination of steviol glycosides in stevia samples by capillary electrophoresis. The method recommended that using a separating agent (TM-b$\mathrm{CD})$ greatly improves the separation efficiency of steviol glycosides. Wang et al. (2015) developed UHPLC -UV method for detection of adulterants (glucose) in stevia products.

Several spectroscopy techniques have been commonly used for quantification of diterpene glycosides in stevia. Mass spectroscopy (MS) is the precise detection method for steviol glycosides (Rajasekaran et al., 2008; Jackson et al., 2009). Shah et al. (2012) developed a LC-MS/MS method for the characterization of steviol glycosides in foods. Kakigi et al. (2013) developed an analytical method for characterizing stevia sweeteners in soft drinks by using LC and MS methods. Kubica et al. (2015) reported a method (high-performance liquid chromatography and tandem mass spectroscopy with electrospray ionisation (HPLC-ESI-MS/MS) for the determination of synthetic sweeteners (acesulfame-K, aspartame, alitame, cyclamate, saccharine, sucralose, neohesperidin dihydrochalcone, neotame) and steviol glycosides (steviol, steviolbioside, rebaudioside A, rebaudioside $\mathrm{C}$ and stevioside) in beverages.

Another method for detection of steviol glycosides is NMR spectroscopy. Stevioside and rebaudioside A-C have been detected by $1 \mathrm{H}$ NMR spectroscopy (Inamake et al., 2010). Furthermore, reference compounds are not used for identification of desired compounds in NMR spectroscopy as compared to HPLC and LC-UV method (Kakigi et al., 2013).

\section{FUTURE PROSPECTS}

Stevia extracts are increasingly used in ice creams, soft drinks and juices and various other products. Apart from this, stevia sweeteners have found its use in bakery and confectionery items too. According to future market insight report, stevia market is expected to reach about 15 percent of the total sweetener market by 2020 worldwide. Additionally, stevia market is affected by the requirement of efficient alternatives for artificial sweetener products due to changing consumer lifestyle and increasing product visibility in urban areas. At the same time, many health problems resulted by using intense sweeteners. Consequently, consumers shifted their preference to natural low calorie sweeteners which is a main factor for driving growth of stevia market. Stevia rebaudiana has high sweetening potential due to stevioside and rebaudioside-A, but the conventional methods of isolation of these glycosides involve long extraction and purification process. So, to make best use of product yield is a challenging problem. Therefore, main emphasis must be on developing new methods for isolation of these glycosides. Simultaneously, development of new varieties having more rebaudioside-A content than stevioside and higher leaf stem ratio and quality are desirable.

\section{Conclusion}

Stevia rebaudiana is a sweet diterpenoid glycosides containing plant of Asteraceae family. Stevioside and rebaudioside-A are two major sweet diterpene glycosides present mostly in the leaves. Stevioside is 300 times sweeter than sugar but with bitter after taste however, rebaudioside-A is having more sweeteness than stevioside. There are thousands of patents, literature available for extraction, purification and quantitative estimation of steviol glycosides. In this review, we have tried to provide the all available information regarding different extraction, purification and estimation processes of steviol glycosides. Extraction methods are generally categorised into conventional and non-conventional methods. Modern extraction or non-conventional extraction methods are the most popular methods for the same because of its merits like reduction in extraction time, higher extract yield and less solvent consumption. But, still conventional methods are being used for steviol glycosides extraction in small scale industries due to its lower cost.

\section{REFERENCES}

Abdullateef, R.A. and Osman, M. (2012). Studies on effects of pruning on vegetative traits in Stevia rebaudiana Bertoni (compositae). Int. J. Biol., 4:146-153.

Abelyan, V.A., Balayan, A.M., Ghochikyan, V.T. and Markosyan, A.A. (2004). Transglycosylation of stevioside by cyclodextrin glucanotransferases of various groups of microorganisms. Appl. Biochem. Micro., 40:129-134.

Abelyan, V., Markosyan, A. and Abelyan, L. (2010). Process for manufacturing a sweetener and use thereof. US patent 8,298,601 B2.

Abou, A.E., Abou, A.A. and Abu, M.F. (2010). Physico-chemical assessment of natural sweeteners stevioside produced from Steviare baudiana Bertoni plant. Afr. J. Food Sci.,4: 269-281.

Afandi, A., Sarijan, S. and Shaha, R.K. (2013). Optimization of rebaudioside A extraction from Stevia rebaudiana (Bertoni) and quantification by high performance liquid chromatography analysis. J. Trop. Resour. Sustain. Sci., 1:62-70.

Ahmed, M.J. and Smith, R.M. (2002). Determination of stevioside by high performance liquid chromatography with pulsed amperometric detection. J. Sep. Sci.,25: 170-172.

Ahmed, M.S. and Dobberstein, R.H. (1982). Stevia rebaudiana II. High performance liquid chromatographic separation and quantification of stevioside, rebaudioside A and rebaudioside C. J. Chromatogr., 236: 523-526. 
Ahmed, M.S., Dobberstein, R.H. and Farnsworth, N.R. (1980). Stevia rebaudiana I. Use of p-bromophenacyl bromide to enhance ultraviolet detection of water soluble organic acids (steviolbioside and rebaudioside B) in high performance liquid chromatographic analysis. J. Chromatogr., 192: 387-393.

Akashi, H., Yokoyama, Y. and Osada, M. (1975). Extraction and purification of steviosides. Japan Kokai 75-24300.

Anton, S., Martin, C., Han, H., Coulon, S., Cefalu, W. and Geiselman, P. (2010). Effects of stevia, aspartame, and sucrose on food intake, satiety and postprandial glucose and insulin levels. Appetite, 55: 37-43.

Anvari, M. and Khayat, G. (2016). Separation and purification of rebaudioside A from extract of Stevia rebaudiana leaves by macroporous adsorption resins. Pol. J. Chem. Technol., 18: 127-132.

Arya, A., Kumar, S. and Kasana, M.S. (2012). Anti-inflammatory activity of in vitro regenerated calli and in vivo plant of Stevia rebaudiana (Bert.) Bertoni. IJSRP., 2: 1-5.

Ayyappa, B., Kanchi, S., Singh, P., Myalowenkosi, I.S. and Bisetty, M.D.K. (2015). Analytical evaluation of steviol glycosides by capillary electrophoresis supported with molecular docking studies. J. Iran. Chem. Soc., 12: 127 $-136$.

Benford, D.J., Di Novi, M. and Schlatter, J. (2006). Safety evaluation of certain food additives: steviol glycosides (PDF). WHO Food Additives Series (World Health Organization Joint FAO/WHO Expert Committee on Food Additives (JECFA), 54:140.

Blumenthal, M. (1996). Perspectives of FDA'S new stevia policy, after four years, the agency lifts its ban -but only partially, Whole Foods Magazine, Febraury 1-5.

Brandle, J. (1999). Genetic control of rebaudioside A and C in leaves of the sweet herb, Stevia rebaudiana. Can. J. Plant. Sci., 79: 85-92.

Cacciola, F., Delmonte, P., Jaworska, K., Dugo, P., Mondello, L. and Rader, J.I. (2011). Employing ultra high pressure liquid chromatography as the second dimension in a comprehensive two-dimensional system for analysis of Stevia rebaudiana extracts. $J$. Chromatogr. A, 1218: 2012-2018.

Carakostas, M., Curry, L., Boileau and Brusick, D. (2008). Overview: the history, technical function and safety of rebaudioside $\mathrm{A}$, a naturally occurring steviol glycoside, for use in food and beverages. Food. Chem. Toxicol., 46: $\mathrm{S} 1-\mathrm{S} 10$

Carakostas, M., Prakash, I., Kinghorn, A.D., Wu, C.D. and Soejarto, D.D. (2012). Steviol glycosides. Alternative Sweeteners, 4th ed., Revised and Expanded.(ed O'Brien N.L.). Marcel Dekker: New York, NY, USA. pp. 159180.

Chan, P., Xu, D.Y., Liu, J.C., Chen, Y.J., Tomlinson, B., Huang, W.P. and Cheng, J.T. (1998). The effect of stevioside on blood pressure and plasma catecholamines in spontaneously hypertensive rats. Life Sci.,63: 16791684.

Chang, S.S. and Cook, J.M. (1983). Stability studies of stevioside and rebaudioside A in carbonated beverages. $J$. Agr. Food. Chem.,31: 409-412.

Chatsudthipong,V. and Muanprasat, C. (2009). Stevioside and related compounds: therapeutic benefits beyond sweetness. Pharmacol.Therapeut.,121: 41-54.

Chaturvedula, V.S.P. and Zamora, J. (2014). Reversed-phase
HPLC analysis of steviol glycosides isolated from Stevia rebaudiana Bertoni. Food Nutr. Sci., 5: 17111716.

Chaturvedula, V.S.P., Chen, S., Yu, O. and Mao, G. (2013a). Isolation, NMR spectral analysis and hydrolysis studies of a hepta pyranosyl diterpene glycoside from Stevia rebaudiana Bertoni. Biomolecules, 3: 733-740.

Chaturvedula, V.S.P., Clos, J.F., Joshua, R., Milanowski, D., Mocek, U., Dubois, G.E. and Prakash, I. (2011). Minor diterpenoid glycosides from the leaves of Stevia rebaudiana. Phytochem.Lett., 4: 209-212.

Chaturvedula, V.S.P., Yu, S.C.O. and Mao, G. (2013b). NMR spectral analysis and hydrolysis studies of rebaudioside N, a minor steviol glycoside of Stevia rebaudiana Bertoni. Food Nutr. Sci., 4: 1004-1008.

Chaturvedula, V.S.P. (2014). Isolation and structural characterization of a new minor penta $\beta$-d-glucopyranosyl diterpene from Stevia rebaudiana Bertoni. Am. J. Plant Sci.,5: 3519-3525.

Chaya, S.C., Mondal. S., Majumdar, G.C. and De, S. (2011). Clarification of Stevia extract by ultrafiltration: selection criteria of the membrane and effects of operating conditions. Food Bioprod. Process., 90: 525532.

Cheng, T.F. and Chang, W.H. (1983). Studies on the non-stevioside components of stevia extracts. Ko Hsueh $\mathrm{Fa}$ Chan Yueh Kan, 11: 96-108.

Cheng, T.F., Chang, C.Y. and Chang, W.H. (1985). A study on the purification of steviosides with use of ionexchange resins. J. Chinese Agri. Chem. Society, 23: 178-190.

Chester, K., Tamboli, E.T., Singh, M. and Ahmad, S. (2012). Simultaneous quantification of stevioside and rebaudioside $\mathrm{A}$ in different stevia samples collected from the Indian subcontinent. J. Pharm. Bioall. Sci., 4: 276-81.

Choi, Y. H., Kim, I. and Yoon, K.D. (2002). Supercritical fluid extraction and liquid chromatographicelectrospray mass spectrometric analysis of stevioside from Stevia rebaudiana leaves. Chromatogr. A,55: 617-620.

Cioni, P.L., Morelli, L., Andolfi, L., Macchia, M. and Ceccarini, L. (2006). Qualitative and quantitative analysis of essential oils of five lines of Stevia rebaudiana Bert.genotypes cultivated in Pista (Italy). J. Essent. Oil Res., 18: 76-79.

Crammer, B. and Ikan, R. (1986). Sweet glycosides from the Stevia plants. Chem. Britain, 22: 915-916.

Dacome, A.S., Silva, C.C., Costa, C.E.M., Fontana, J.D., Adelmann, J. and Costa, S.C. (2005). Sweet diterpene glycosides balance of a new cultivar of Stevia rebaudiana (Bert.) Bertoni: isolation and quantitative distribution by chromatographic, spectroscopic, and electrophoretic methods. J. Process Biochem., 40: 3587 3594.

Darise, M., Kohda, H., Mizutani, K., Kasai, R. and Tanaka, O. (1983). Chemical constituents of flowers of Stevia rebaudiana Bertoni. Agric. Biol. Chem., 47: 133-135.

Das, S., Das, A.K., Murphy, R.A., Punwani, I.C., Nasution, M.P. and Kinghorn, A.D. (1992). Evaluation of the cariogenic potential of the intense natural sweeteners stevioside and rebaudioside A. Caries Res., 26: 363366. 
Debnath, M. (2008). Clonal propagation and antimicrobial activity of an endemic medicinal plant Stevia rebaudiana. J. Med. Plants Res., 2:45-51.

Deshmukh, S.R. and Kedari, V.R. (2014). Isolation, purification and characterization of sweetners from Stevia rebaudiana (Bertoni) for their anticancerous activity against colon cancer. World J. Pharm. Sci., 3: 1394-1410

Englert, M., Kaiser, C., Schwack, W. and Vetter, W. (2016).Isolation of (five) steviol glycosides from a Stevia rebaudiana formulation by gradient elution countercurrent chromatography. Chromatogr. A, 79: 275-284.

Erkucuk, A., Akgun, I.H. and Celiktas, Y.O. (2009). Supercritical $\mathrm{CO}_{2}$ extraction of glycosides from Stevia rebaudiana leaves: identification and optimization. $J$. Supercrit. Fluid.,51: 29-35.

Fu, Q.U., Guo, Z., Zhang, X., Liu, Y. and Liang, X. (2012).Comprehensive characterization of Stevia Rebaudiana using two-dimensional reversed-phase liquid chromatography/hydrophilic interaction liquid chromatography. J. Sep. Sci.,35: 1821-1827.

Fuh, W.S. and Chiang, B.H. (1990). Purification of steviosides by membrane and exchange processes. $J$. Food Chem., 55: 1454-1457.

Fujinuma, K., Saito, K., Nakazato, M., Kikuchi, Y., Ibe, A. and Nishima, T. (1986).Thin layer chromatographic detection and liquid chromatographic determination of stevioside and rebaudioside $\mathrm{A}$ in beverages and foods following reverse phase column chromatography. $J$. Assoc. Off. Anal. Chem.,69: 799-802.

Gardana, C., Scaglianti, M. and Simonetti, P. (2010). Evaluation of steviol and its glycosides in Stevia rebaudiana leaves and commercial sweetener by ultra-high performance liquid chromatography-mass spectroscopy. J.Chromatogr. A, 1217: 1463-1470.

Gasmalla, M.A.A., Yang, R. and Hua, X. (2014). Stevia rebaudiana Bertoni: an alternative sugar replacer and its application in food industry. Food Eng. Rev., 6: 150162.

Gentry, A.H. (1996). Field guide of the families and genera of woody plants to Northwest South America with supplementary notes on herbaceous Taxa. The University of Chicago Press, 895p.

Geuns, J.M.C. (2003). Stevioside. Phytochemistry, 64: 913921.

Ghanta, S.A., Banerjee, A., Podder and Chattopadhyay, S. (2007).Oxidative DNA damage preventive activity and anti oxidant potential of Stevia rebaudiana (Bertoni) a natural sweetener.J. Agr. Food. Chem., 55: 962-967.

Giavanetto, R. H. (1990). Method for the recovery of steviosides from plant raw material. US patent 4,892 938.

Giuffre, L., Romaniuk, R. and Ciarlo, E. (2013). Stevia, ka'a he'e, wild sweet herb from South America - an overview.Emir. J. Food Agric., 25: 746-750.

Gonzalez, I.A., Yolanda, M.O. and David, B.A. (2014). Validation of HPLC-UV method for determination of minor glycosides contained in Stevia rebaudiana Bertoni leaves. Biomed. Chromatogr., 29:733-738.

Gonzalez, I.A., Ordonez, Y.M. and Ancona, D.B. (2015). Determination of rebaudioside A and stevioside in leaves of $S$. Rebaudiana Bertoni grown in Mexico by a validated HPLC method.Am. J. Analyt. Chem., 6:878888.

Goyal, S. K., Samsher and Goyal, R. K. (2010). Stevia (Stevia rebaudiana) a bio-sweetener: a review. Int. J. Food Sci. Nutr.,61: 1-10.

Hansen, H.J. (2010). Future use of steviol glycosides: results of a survey in the German beverage industry. $J$. Verbrauch. Lebensm., 5: 237-239.

Hashimoto, Y., Moriyasu, M., Nakamura, S., Ishiguro, S. and Komuro, M. (1978).High performance liquid chromatographic determination of Stevia components on a hydrophilic packed column. J. Chromatogr, 161: 403-405.

He, B., Liu, Y. and Shi, Z. (1994). Application of an adsorbant $\mathrm{AB}-8$ in extraction and separation of stevioside. Huase Yingyong, 11: 16-19.

Hearn, L. and Subedi, P. (2009).Determining levels of steviol glycosides in the leaves of Stevia rebaudiana by near infrared reflectance spectroscopy. J. Food Compos. Anal., 22: 165-168.

Herranz, L.M., Barrajon, C.E., Beltran, D.R., Joven, J. and Micol, V. (2010). Stevia is a source for alternative sweeteners: potential medicinal effects. Agro Food Ind. Hi Tec, 21: 38-42.

Hoekstra, B., Traub, J., Chamberlain, K., Baugh, S. and Venkataraman, S.K. (2009).Comparative study of HPLC methods for the analysis of diterpene glycosides from Stevia rebaudiana. Planta Med., 75: 1003-1013.

Hossain, M.A., Siddique, A.B., Rahman, S.M.M. and Hossain, M.A. (2010). Chemical composition of the essential oils of Stevia rebaudiana Bertoni leaves. Asian J. Tradit. Med., 5: 56-61.

Hsieh, M.H., Chan, P., Sue, Y.M., Liu, J.C., Liang, T.H., Huang, T.Y., Tomlinson, B., Chow, M.S., Kao, P.F. and Chen, Y.J. (2003). Efficacy and tolerability of oral stevioside in patients with mild essential hypertension: a two-year, randomized, placebo-controlled study. Clin.Ther., 25: 2797-2808.

Huang, X.Y., Fu, J.F. and Di, D.L. (2010). Preparative isolation and purification of steviol glycosides from Stevia rebaudiana Bertoni using high speed counter current chromatography. Sep. Purif. Technol., 71: 220224

Huber, J., Borie, N., Chollet, S., Perret, J., Barbet, M. C., Berger, M., Dayde, J. and Renault, J.H. (2015). Intensified separation of steviol glycosides from a crude aqueous extract of Stevia rebaudiana leaves using centrifugal partition chromatography. Planta Med., 81: 1614-1620.

Ibrahim, M.A., Rodenburg, D.L., Alves, K., Perera, W.H., Fronczek, F.R., Bowling, J. and McChesney, J.D. (2016). Rebaudiosides R and S, minor diterpene glycosides from the leaves of Stevia rebaudiana. J. Nat. Prod., 79:1468-1472.

Inamake, M.R., Shelar, P.D., Kulkarni, M.S., Katekar, M.S. and Tambe, R. (2010). Isolation and analytical characterization of stevioside from leaves of Stevia rebaudiana Bert; Asteraceae. Int. J. Res. Ayurveda Pharm., 1: 572-581.

Ishizone, H. (1979). Separation and purification of stevioside. Japan Kokai Tokkyo Koho, 79: 400.

Jackson, A., Tata, A., Wu, C., Perry, R., Haas, G., West, L. and Cooks, R.G. (2009). Direct analysis of stevia leaves 
for diterpene glycosides by desorption electrospray ionization mass spectroscopy. Analyst, 1345: 867-874.

Jadhao, D.B., Katekhaye, S.D. and Thorat, B.N. (2011).Improved RP-HPLC method for quantitative estimation of stevioside in Stevia rebaudiana Bertoni Burm.Int. J. Phyto. Pharm., 1: 27-34.

Jaitak, V., Bandna, Singh, B. and Kaul, V.K. (2009).An efficient microwave-assisted extraction process of stevioside and rebaudioside-A from Stevia rebaudiana (Bertoni).Phytochem. Analysis, 20: 240-245.

Javad, S., Naz, S., Ilyas, S., Tariq, A. and Aslam, F. (2014).Optimization of the microwave assisted extraction and its comparison with different conventional extraction methods for isolation of stevioside from Stevia rebaudiana. Asian J. Chem., 26: 8043-8048.

Jaworska, K., Krynitsky, A.J. and Rade, R.J.I. (2012). Simultaneous analysis of steviol and steviol glycosides by liquid chromatography with ultraviolet detection on a mixed-mode column: application to stevia plant material and stevia-containing dietary supplements. $J$. AOAC Int.,95: 1588-1596.

JECFA (Joint FAO/WHO Expert Committee on Food Additives).(2010). Steviol glycosides.Compendium of food addditive specifiations, 73th meeting, FAO JECFA monographs 10, pp.17-22.

Jeppesen, P., Gregersen, S., Gregersen, S., Alstrupp, K. and Hermansen, K. (2002). Stevioside induces antihyperglycaemic, insulinotropic and glucagonostatic effects in vivo: studies in the diabetic Goto-Kakizaki (GK) rats. Phytomedicine, 9: 9-14.

Jonnala, K.K., Kiran, B.G., Kaul, V.K. and Ahuja, P.S (2006).Process for production of steviosides from Stevia rebaudiana Bertoni.US patent 0142555.

Kakigi, Y., Suzuki, T., Icho, T., Uyama, A. and Mochizuki, N. (2013).Classification of stevia sweeteners in soft drinks using liquid chromatography and time-of-flight mass spectroscopy.Food Addit.Contam. A,30: 20432049.

Kamauchi, H., Kon, T., Kinoshita, K., Takatori, K. and Takahashi, K. (2015). New diterpenoids isolated from Stevia rebaudiana fermentedby Saccharomyces cerevisiae. Tetrahedron let.,56: 4377-4382.

Kasai, R., Yamaguchi, H. and Tanaka, O. (1987). High-performance liquid chromatography of glycosides on a new type of hydroxyapatite column. J. Chromatogr., 407: 205-210.

Katayama, O., Sumida, T., Hayashi, H. and Mitsuhashi, H. (1976). The practical application of stevia and research and development data.Japan: I.S.U. Company, 747p.

Kaur, G., Pandhair, V. and Cheema, G.S. (2014). Extraction and characterization of steviol glycosides from Stevia rebaudiana Bertoni leaves. J. Med. Plants. Stud., 2: 4145.

Kaushik, R., Narayanan, P., Vasudevan, V., Muthukumaran, G. and Antony, U. (2010). Nutrient composition of cultivated stevia leaves and the influence of polyphenols and plant pigments on sensory and antioxidant properties of leaf extracts. J. Food Technol., 47: 27-33.

Kedik, S.A., Yartsev, E.I. and Stanishevskaya, I.E. (2009).Antiviral activity of dried extract ofStevia.Pharm. Chem. J.,43: 198-199.

Khaled, A., Shams, N.S., Azim, A., Saleh, I.A., Hegazy,
M.E.F., Missiry, M.M. and Hammouda, F.M. (2015) Green technology: economically and environmentally innovative methods for extraction of medicinal \& aromatic plants (MAP) in Egypt. J. Chem. Pharm. Res., 7: 1050-1074.

Khoddami, A., Wilkes, M.A. and Roberts, T.H. (2013).Review-techniques for analysis of plant phenolic compounds.Molecules, 18: 2328-2375.

Kienle, U. (1990). Method of making a natural sweetener based on Stevia rebaudiana, and use thereof. Int. Cl.5 A61K 35/78. U.S. Cl. 424/195.1, 586690 Sep. 24, 1990. Chemical abstracts No. 111, 22442z.

Kienle, U. (2007). Stevia rebaudiana natural sweetness in the bureaucratic jungle. J. Culinaire, 5: 59-69.

Kienle, U. (2010). A natural fabric makes career. J. Verbrauch. Lebensm., 5: 199-203.

Kinghorn, A.D. and Soejarto, D.D. (1985).Current status of stevioside as a sweetening agent for human use. In: Economic and medicinal plant research, vol.1. (eds. Wagner, H., Hikino, H. and Farnsworth, N.R.)London, New York Academic Press.pp. 1-52.

Kinghorn, A.D., Nanayakkara, N.P.D., Soejarto, D.D., Medon, P.J. and Kamath, S. (1982). Potential sweetening agents of plant origin: I. Purification of Stevia rebaudiana sweet constituents by droplet counter-current chromatography. J. Chromatogr., 237: 478-483.

Kinghorn, A.D. (2002). Overview.Stevia: the Genus Stevia (Medicinal and Aromatic Plants-Industrial Profiles.(ed. Kinghorn, A.D.). Taylor and Francis: London ,pp.1-17.

Kitada, Y., Sasaki, M. and Yamazoe, Y. (1989).Simultaneous determination of stevioside, rebaudioside $\mathrm{A}$ and $\mathrm{C}$ and dulcoside $\mathrm{A}$ in foods by highperformance liquid chromatography.J. Chromatogr, 474: 447-451.

Kohda, H., Kasai, R., Yamasaki, K., Murakami, K. and Tanaka, P. (1976).Steviosides from Stevia rebaudiana Bertoni.Phytochemistry, 15: 981-982.

Kolb, N., Herrera, J.L., Ferreyra, D.J. and Utiana, R.F. (2001). Analysis of sweet diterpene glycosides from Stevia rebaudiana: Improved HPLC method. J. Agr. Food Chem., 49: 4538-4541.

Koshiro, C.S.K.K. (1980).Stevia components as sweetening agents and antibiotics. Japan Patent 55-92323.

Kroyer, G. (2010). Stevioside and stevia-sweetener in food: application, stability and interaction with food ingredients. J. Verbrauch. Lebensm.,5: 225-229.

Kubica, P., Namiesnik, J. and Wasik, A. (2015). Determination of eight artificial sweeteners and common Stevia rebaudiana glycosides in non-alcoholic and alcoholic beverages by reversed-phase liquid chromatography coupled with tandem mass spectroscopy. Anal.Bioanal. Chem., 407: 1505-1512.

Kumari, M. and Chandra, S. (2015).Phytochemical studies and estimation of major steviol glycosides in varied parts of Stevia rebaudiana.Int. J. Pharm. Pharm. Sci., 7: $62-65$.

Kumari, N., Rana, R.C., Sharma, Y.P. and Kumar, S. (2016a). Dynamics of steviol glycosides (stevioside and rebaudioside-A) with growth and development of Stevia rebaudiana Bertoni. JANS., 8: 1953-1958. 1953-1958.

Kumari, N., Rana, R.C., Sharma, Y.P. and Kumar, (2016b).Variations in stevioside and rebaudioside-A content in Stevia rebaudiana under different growing 
conditions. Int. J. Agr. Sci., 8: 1329-1331.

Kuo, W.S. and Chiang, B.H. (1987). Recovery of glutamic acid from fermentation broth by membrane processes. $J$. Food Sci., 52: 1401.

Kuroda, A. and Kamiyama, S. (1979). Stevia leaf extract purification. Patent-Japan Kokai Tokkyo Koho-79 76,600: 3 .

Lasekan, O. and Naidu, K.R.M. (2013). Changes in the volatile constituents of the leaves of Stevia rebaudiana Bertoni caused by different drying procedures. J. Food Agric. Environ., 11: 190-194.

Lee, C.N., Wong, K., Liu, J., Chen, Y., Chen, J. and Chan, P. (2001). Inhibitory effect of stevioside on calcium influx to produce anti-hypertension. Planta Med., 67: 796-799.

Li, J., Chen, Z., and Duolong, D. (2012). Preparative separation and purification of rebaudioside A from Stevia rebaudiana Bertoni crude extracts by mixed bed of macroporous adsorption resins. Food Chem., 132: 26827.

Liu, J., Ong, C.P. and Li, S.F.Y. (1997). Subcritical fluid extraction of stevia sweeteners from Stevia rebaudiana. J. Chromatogr. Sci., 35: 446- 450.

Lorenzo, C., Diaz, J.S., Plaza, M., Quintanilla, C. and Alonso, G.L. (2014). Fast methodology of analysing major steviol glycosides from Stevia rebaudiana leaves. Food Chem., 157: 518-523.

Madan, S., Ahmad, S., Singh, G.N., Kohli, K., Singh, Y.K.R. and Garg, M. (2010). Stevia rebaudiana (Bert.)Bertonia review. Indian J. Nat. Prod.Resour., 1: 267-286.

Magomet, M., Tomov, T., Somann, T. and Abelyan, V.H. (2011).Process for manufacturing a sweetener and use thereof. Google patents 7,862,845B2.

Mantovaneli, I.C.C., Ferretti, E.C., Simoes, M.R. and Silva, F.C. (2004). The effect of temperature and flow rate on the clarification of the aqueous stevia-extract in a fixedbed column with zeolites. Braz. J. Chem. Eng., 21: 449458.

Markovic, I.S., Darmati, Z.A. and Abramovic, B.F. (2008). Chemical composition of leaf extract of Stevia rebaudianaBertoni grown experimentally in Vojvodina. J. Serb. Chem. Soc., 73: 283-297.

Martono, Y., Riyanto, S., Rohman, A., Martono, S. (2016). Effect of mobile phase composition, organic modifier and flow rate on selectivity and retention of stevioside and rebaudioside Aon isocratic RP-HPLC analysis. IJPCR, 8: 397-402.

Masuyama, F. (1980). Stevioside sweetener purification from Stevia rebaudiana leaves. Japan Kokai Patent $80,07,039$

Mauri, P., Catalano, G., Gardana, C. and Pietta, P. (1996). Analysis of stevia glycosides by capillary electrophoresis. Electrophoresis, 17: 367-371.

Mc Garvey, B.D., Attygalle, A.B., Starratt, A.N., Xiang, B., Schroeder, F.C., Brandle, J.E. and Meinwald, J. (2003). New non-glycosidic diterpenes from the leaves of Stevia rebaudiana. J. Nat. Prod., 66: 1395-1398.

Meneni, S. and Chaturvedula, V.S.P. (2015). Continuation of reversed-phase HPLC analysis studies of steviol glycosides isolated from Stevia rebaudiana Bertoni. J. Food Res., 4: 87-91.

Minne, V.J., Compernolle, F., Toppet, S. and Geuns, J.M. (2004). Steviol quantification at the picomole level by high-performance liquid chromatography. J. Agr. Food
Chem., 52: 2445-2449.

Mishra, P., Singh, R., Kumar, U. and Prakash, V. (2010). Stevia rebaudiana - a magical sweetener. GJBB, 5: 6274.

Mitchell, H.L. (2006). Sweeteners and sugar alternatives in food technology. Blackwell Publishing Ltd., Oxford, UK, pp. 341-347.

Mohan, K. and Robert, J. (2009). Hepatoprotective effects of Stevia rebaudiana Bertoni leaf extract in CCl4-induced liver injury in albino rats. Med. Aromat. Plant Sci. Biotechnol., 3: 59-61.

Mondaca, R.L., Galvez, A.G., Bravo, L.Z. and Hen, K. (2012). Stevia rebaudiana Bertoni, source of a highpotency natural sweetener: a comprehensive review on the biochemical, nutritional and functional aspects. Food Chem., 132: 1121-1132.

Musa, A., Gasmalla, M.A.A., Miao, M., Zhang, T., Aboshora, W., Eibaid, A. and Jiang, B. (2014). Separation and structural characterization of tri-glucosyl-stevioside. J. Acad. Indus. Res., 2: 593-598.

Nikolova, D. B., Bankova, V. and Popov, S. (1994). Separation and quantification of stevioside and rebaudioside-A in plant extracts by normal phase high performance liquid chromatography and thin layer chromatography: a comparison. Phytochem. Analysis, 5: 81-85.

Oddone, B. (1999). How to growStevia.Guarani Botanicals, Inc., Pawcatuck, Connecticut, pp. 1-30.

Okane, H. and Kamata, L. (1977). Latino wit and wisdom. Japan Patent 52,057,198.

Oshima, Y., Saito, J. and Hikino, H. (1986). Sterebins A, B, $\mathrm{C}$ and $\mathrm{D}$, bis norditerpenoids of Stevia rebaudiana leaves. Tetrahedron, 42: 6443-6446.

Oshima, Y., Saito, J. and Hikino, H. (1988). Sterebins E, F, $\mathrm{G}$ and $\mathrm{H}$, diterpenoids of Stevia rebaudiana leaves. Phytochemistry, 27: 624-626.

Pasquel, A., Meireles, M.A.A., Marque, M.O.M. and Petenate, A.J. (2000). Extraction of stevia glycosides with $\mathrm{Co}_{2}+$ water, $\mathrm{Co}_{2}+$ ethanol, and $\mathrm{Co}_{2}+$ water + ethanol. Braz. J. Chem. Eng., 17:271-282.

Payzant, J.D., Laidler, J.K. and Ippolito, R.M. (1999). Method of extracting selected sweet glycosides from the Stevia rebaudianaplant. U.S. Patent 5,962,678.

Phillips, K.C. (1987). Stevia: steps in developing a new sweetener. Developments in Sweeteners.(ed. Grenby, T.H.). Elsevier Applied Science London, pp. 1-43.

Piasecka, A., Krzeminnska, I. and Tys, J. (2014). Physical methods of microalgal biomass pretreatment.Int. $\mathrm{Ag}$ rophys., 28: 341-348.

Pieri, V., Belancic, A., Morales, S. and Stuppner, H. (2011).Identification and quantification of major steviol glycosides in Stevia rebaudiana purified extracts by $1 \mathrm{H}$ NMR spectroscopy. J. Agr. Food Chem., 59: 43784384 .

Pol, J., Ostra, E.V., Karasek, P., Roth, M., Benesova, K., Kotlarikova, P. and Caslavsky, J. (2007). Comparison of two different solvents employed for pressurised fluid extraction of stevioside from Stevia rebaudiana: methanol versus water. Anal. Bioanal. Chem., 388: $1847-1857$.

Prakash, I., Bunders, C., Devkota, K.P., Charan, R.D., Ramirez, C., Priedemann, C. and Markosyan, A. (2014a). Isolation and Characterization of a novel rebaudioside $\mathrm{M}$ isomer from a bioconversion reaction of 
rebaudioside A and NMR comparison studies of rebaudioside M isolated from Stevia rebaudiana Bertoni and Stevia rebaudiana morita. Biomolecules, 4:374-389.

Prakash, I., Campbell, M. and Chaturvedula, V.S.P. (2012). Catalytic hydrogenation of the sweet principles of Stevia rebaudiana, rebaudioside $\mathrm{B}$, rebaudioside $\mathrm{C}$ and rebaudioside $\mathrm{D}$ and sensory evaluation of their reduced derivatives. Int. J. Mol. Sci., 13: 15126-15136.

Prakash, I., Clos, J.F. and Chaturvedula, V.S.P. (2011). Stability of steviol glycosides in mock beverages under acidic conditions. IJPSR, 3: 421-425.

Prakash, I., Dubois, G., Clos, J., Wilkens, K. and Fosdick, L. (2008). Development of rebiana, a natural, non-caloric sweetener. Food Chem. Toxicol., 46:575-582.

Prakash, I., Markosyan, A. and Bunders, C. (2014b). Development of next generation stevia sweetener: rebaudioside M. Foods, 3: 162-175.

Puri, M., Sharma, D. and Tiwari, A.K. (2011). Downstream processing of stevioside and its potential applications. Biotechnol. Adv., 29: 781-789.

Puri, M., Sharma, D., Barrow, C.J. and Tiwari, A.K. (2012). Optimisation of novel method for the extraction of steviosides from Stevia rebaudiana leaves. Food Chem., 132: 1113-1120.

Purkayastha, S., Markosyan, A. and Malsagov, M. (2012). Process for manufacturing a sweetener and use thereof. Patents 8,334,006.

Rajab, R., Mohankumar, C., Murugan, K., Harish, M. and Mohanan, P.V. (2009). Purification and toxicity studies of stevioside from Stevia rebaudiana Bertoni. Toxicol. Int., 16: 49-54.

Rajasekaran, T., Ramakrishna, A., Sankar, U.K., Giridhar, P. and Ravishankar, G.A. (2008). Analysis of predominant stevioside in Stevia rebaudiana Bertoni by liquid chromatography/electrospray ionization- mass spectroscopy. Food Biotechnol., 22: 179-188.

Ramesh, K., Singh, V. and Megeji, N.W. (2006). Cultivation of Stevia (Stevia rebaudiana Bertoni): a comprehensive review. Adv. Agron., 89: 137-177.

Rao, A.B., George, S.A., Alavala, S., Meshram, H.M. and Shekar, K.C. (2015). Metal salts assisted enzyme-based extraction of stevioside from the leaves of Stevia rebaudiana Bertoni. Adv. Biosci. Biotechnol., 6: 734 743.

Rao, A.B., Prasad, E., Roopa, G., Sridhar, S. and Yerrapragada, V.L.R. (2012). Simple extraction and membrane purification process in isolation of steviosides with improved organoleptic activity. $A d v$. Biosci. Biotechnol., 3: 327-335.

Reshu, G., Vidushi, Y. and Manvi, R. (2014). A review on importance of natural sweetener, a zero caloric plant- stevia- having medicinal and commercial importance. IJFANS, 3:90-94.

Rodenburg,D.L., Alves, K., Perera, W.H., Ramsaroop, T., Carvalho, R. and McChesney, J.D. (2016) Development of HPLC analytical techniques for diterpene glycosides from Stevia rebaudiana (Bertoni) Bertoni: strategies to scale-up. J. Brazil. Chem. Soc., 27: 1406-1412.

Roy, A. and De, S. (2014). Extraction of steviol glycosides using novel cellulose acetate pthalate (CAP)- polyacrylonitrile blend membranes. J. Food Eng., 126: 7-16.

Saifi, M., Ali, A., Saini, M., Nasrullah, N., Khan, S. and
Abdin, M.Z. (2014). A rapid and efficient high performance thin layer chromatographic (HPTLC) method for simultaneous analysis of stevioside and rebaudioside-A in Stevia rebaudiana. Int. J. Pharm. Pharm. Sci., 6: 455 $-462$.

Samah, N.A., Hisham, A.D.A. and Rahim, S.A. (2013). Determination of stevioside and rebaudioside A in Stevia rebaudiana leaves via preparative high performance liquid chromatography (prep-HPLC). IJCEE, 4: 86-89.

Satishkumar, J., Sarvanan, M.M. and Seethalakshmi, I. (2008). In-vitro antimicrobial and antitumor activities of Stevia rebaudiana (Asteraceae) leaf extracts. Trop. J. Pharm. Res., 7: 1143-1149.

Schiffman, S.S., Miller, S.E.A., Graham, B.G., Bennett, J.L., Booth, B.J. and Bishay, D.N. (2000). Effect of temperature, $\mathrm{pH}$, and ions on sweet taste. Physiol. Behav., 68: 469-481.

Serio, L. (2010). La Stevia rebaudiana, une alternative au sucre. Phytotherapie, 8: 26-32.

Shah, R., Jager, L.S. and Begley, T.H. (2012). Simultaneous determination of steviol and steviol glycosides by liquid chromatography-mass spectroscopy. Food. Addit. Contam. A., 29: 1861-1871.

Sharma, M., Thakral, N.K. and Thakral, S. (2009). Chemistry and in vivo profile of ent- kaurene glycosides of Stevia rebaudiana Bertoni- an overview. Nat. Prod. Radiance, 8: 181-189.

Shock, C.C. (1982). Experimental cultivation of rebaudi's Stevia in California. University of California, Davis. AgronomyProgress Report No. 122, 9p.

Silva, F.V., Bergamasco, R., Andrade, C.M.G., Pinheiro, N., Machado, N.R.C.F., Reis, M.H.M., Araujo, A.A. and Rezende, S.L. (2007). Purification process of stevioside using zeolites and membrane. Int. J. Chem. React. Eng., 5: $1-6$.

Silva, P.A., Oliveira, D.F., Prado, N.R., Carvalho, D.A. and Carvalho, G.A. (2008). Evaluation of the antifungal activity by plant extracts against Colletotrichum gloeosporioides PENZ. Cienc. Agrotec., 32: 420-428.

Soejarto, D.D. (2002). Ethnobiology of stevia and Stevia rebaudiana. Stevia: the genus Stevia (Medicinal and Aromatic Plants - Industrial Profiles). (ed. Kinghorn A.D.), Taylor and Francis/CRC Press, New York/ London, UK. pp. 40-67.

Surana, S.J., Gokhale, S.B., Rajmane, R.A. and Jadhav, R.B. (2006). Nonsaccharide natural intense sweeteners: an overview of current status. Nat. Prod. Radiance, 5: 270278.

Takahashi, K., Iwata, Y., Mori, S. and Shigeta, S. (1998).Invitroanti-HIV activity of extract from Stevia rebaudiana. Antivir. Res., 37: A59.

Takahashi, K., Matsuda, M., Ohashi, K., Taniguchi, K., Nakagomi, O., Abe, Y., Mori, S., Sato, N., Okutani, K. and Shigeta, S. (2001). Analysis of anti-rotavirus activity of extract fromStevia rebaudiana. Antivir. Res., 49: 15-24.

Takamura, K., Kawaguchi, M. and Isono, C. (1977). Separation of stevioside. Japan Kokai 77-51069.

Tavarini, S. and Angelini, L.G. (2013). Stevia rebaudiana Bertoni as a source of bioactive compounds: the effect of harvest time, experimental site and crop age on steviol glycoside content and antioxidant properties. J. Sci. Food. Agr.,93: 2121-2129.

Teo, C.C., Tan, S.N., Yong, J.W.H., Hew, C.S. and Ong, 
E.S. (2009). Validation of green-solvent extraction combined with chromatographic chemical fingerprint to evaluate quality of Stevia rebaudiana Bertoni. J. Sep. Sci.,32: 613-622.

Tiwari, S., Arnold, R., Saxena, A., Tiwari, A., Mishra, N., Awasthi, S. and Tiwari, S. (2014). Evaluation of extraction of stevioside and rebaudioside from Stevia rebaudiana bertoni by pressurized hot water extraction. SSJBT, 3: $153-158$

Vanek, T., Nepovim, A. and Valicek, P. (2001). Determination of stevioside in plant material and fruit teas. $J$. Food. Compos. Anal., 14: 383-388.

Vanneste, J., Sotto, A., Courtin, C.M., Van, C.V., Bernaerts, K., Van, I.J., Vandeur, J., Taes, S. and Vander, B.B. (2011). Application of tailor-made membranes in a multi-stage process for the purification of sweeteners from Stevia rebaudiana. J. Food. Eng., 103: 285-293.

Wang, Y.H., Avulaa, B., Tanga, W., Wanga, M., Elsohlya, M.A. and Khan, I.A. (2015).Ultra-HPLC method for quality and adulterant assessment of steviol glycosides sweeteners- Stevia rebaudiana and stevia products. Food. Addit. Contam. A., 32: 674-685.

Woelwer, R.U., Lankes, C., Wawrzun, A. and Wuest, M. (2010). Improved HPLC method for the evaluation of the major steviol glycosides in leaves of Stevia rebaudiana. Eur. Food. Res. Technol., 231: 581-588.

Woelwer, R.U. (2012). The leaves of Stevia rebaudiana (Bertoni), their constituents and the analyses thereof: a review. J. Agr. Food. Chem., 60: 886-895.

Wolwer, R., Tomberg, W. and Wawrzun, A. (2010). Investigations on the stability of stevioside and rebaudioside A in soft drinks. J. Agr. Food. Chem., 58: 12216-12220.

Yabu, R., Takase, M., Toda, K., Tanisoto, K., Yasutake, A. and Iwaeoto, Y. (1977). Studies on stevioside, natural sweetener: effect on the growth of some oral microorganisms. Hiroshima Daigaku Shigaku Zasshi, 9: 12-17.

Yadav, A.K., Singh, S., Dhyani, D. and Ahuja, A.S. (2011). A review on the improvement of Stevia. Can. J. Plant. Sci., 91: 1-27.

Yadav, S.K. and Guleria, P. (2012). Steviol glycosides from stevia: biosynthesis pathway review and their application in foods and medicine. Crit. Rev. Food. Sci. Nutr., 52: 988-98.

Yoda, S.M., Marques, M.O.M., Petenate, A.J. and Meireles, M.A.A. (2003). Supercritical fluid extraction from Stevia rebaudiana Bertoni using $\mathrm{CO}_{2}$ and $\mathrm{CO}_{2}+$ water: extraction kinetics and identification of extracted components. J. Food Eng., 57:125-134.

$\mathrm{Yu}$, Z.R. and Chiang, B.H. (1986). Passion fruit juice concentration by ultra filtration and evaporation. J. Food Eng., 51: 1501.

Zhang, S.Q., Kumar, A. and Kutowy, O. (2000). Membranebased separation scheme for processing sweeteners from stevia leaves. Food. Res. Int., 33: 617-620.

Zimmermann, B.F., Woelwer, R.U. and Papagiannopoulos, M. (2011).Separation of steviol glycosides by hydrophilic liquid interaction chromatography. Food Anal. Methods, 5: 266-271.

Zlabur, J.S., Voca, S., Dobricevic, N., Brncic, M., Dujmic, F. and Brncic, S.R. (2015). Optimization of ultrasound assisted extraction of functional ingredients from Stevia rebaudiana Bertoni leaves. Int. Agrophys., 29: 231-237. 